\title{
A Framework for Green Remodeling Enabling Energy Efficiency and Healthy Living for the Elderly
}

\author{
Sung Jun Park ${ }^{1,2}$ and Mi Jeong Kim ${ }^{3, *}$ \\ 1 Department of Interior and Environmental Design, Keimyung University, Daegu 42601, Korea; \\ sjpark@kmu.ac.kr \\ 2 Department of Architectural Engineering, Keimyung University, Daegu 42601, Korea \\ 3 Department of Housing and Interior Design, Kyung Hee University, Seoul 02447, Korea \\ * Correspondence: mijeongkim@khu.ac.kr; Tel.: +82-2-961-9275
}

Received: 7 July 2018; Accepted: 1 August 2018; Published: 6 August 2018

\begin{abstract}
This study proposes a framework for green remodeling for the elderly that emphasizes the role of designers and the notion of aging in place. Energy efficiency is critical for older persons because many of them spend more time at home and are less likely to heat and cool their homes appropriately. Improving the energy performance of the elderly's housing by green remodeling could promote energy efficiency and healthy living for the elderly. Based on remodeling components derived from related work, key factors to be considered regarding the remodeling for the elderly were investigated. A framework for green remodeling enabling energy efficiency was developed for home upgrades for the elderly. Identifying the area of application and critical components for energy efficiency helps improve the energy performance for the elderly. This study is significant because it considers the elderly's characteristics and experiences in the development of a sustainable remodeling process rather than new-building construction.
\end{abstract}

Keywords: energy efficiency; home remodeling; healthy living; sustainability; elderly's housing

\section{Introduction}

Most studies on health smart homes have emphasized the adoption of cutting-edge technologies in home environments to provide smart services and promote healthy living [1]. However, the concept of 'smart' does not only relate to technology but also to eventually enabling a smart life for residents. Non-technological methods, as long as they are effective and efficient for a healthy living, could be considered in the implementation of health smart homes. Emphasizing sustainability, we became interested in the processes of remodeling home environments to improve performance and health. Rather than new constructions, which causes waste and pollution, governments have recommended a sustainable remodeling approach for home performance upgrades. Sustainable housing design can lessen the impact on the environment, decrease the use of natural resources, and decrease energy consumption [2]. Wilson and Jacob [3] showed that home performance upgrades relating to air pollution could improve the quality of a home environment, resulting in improved occupant health outcomes. They emphasized the link between home performance and associated health outcomes and raised the issue of 'green renovation' associated with the remodeling process and performance upgrades. Promoting improvements in energy efficiency is a crucial issue in home environments. However, little research has been conducted on the improvement of energy performance brought about by remodeling in the domain of health smart homes. In this research, the concept of the health smart home is extended, emphasizing energy management in the housing for the elderly. 
The global aging phenomenon has created a housing problem in terms of older people's health and economic security. Arguably, their health and economic capacity is challenged by the energy efficiency of housing and the rising cost of energy [4]. Choi and Park [5] have argued that a home-improvement strategy, especially in relation to energy efficiency, should be employed for the elderly whose physical, mental, and social functions are lower than those of people in other age groups. Energy efficiency is critical for older people because many older people spend more time at home and are less likely to heat and cool their homes appropriately $[4,6]$. Poor building thermal characteristics that cause inappropriate heating and cooling present a potential risk to elderly occupants by affecting them physiologically, for example, by affecting respiratory and coronary conditions $[4,7,8]$. Older people tend to have lower incomes than younger people and tend to live in inefficient, old housing [9]. Therefore, energy-efficient home upgrades are critical for the successful management of their home energy costs and their health and well-being in daily life. However, current remodeling components for improving energy efficiency only emphasize the economic and environmental aspects of buildings. They do not support the experience of older people whose physical, mental, and social functions are degraded. Proposing a green remodeling framework reflecting the health status and individual needs of the elderly can decrease remodeling costs by concentrating on specific planning factors and items for the elderly in the customized remodeling process.

The purpose of this study is to develop the framework for green remodeling for the elderly by identifying elements that are essential for improving energy performance for healthy living. Improving the energy performance of the houses by remodeling is one alternative for solving environmental problems and can have a great effect on the economics of buildings [10]. Further, identifying the area of application and critical components for energy efficiency helps improve energy performance for the elderly through the remodeling process. In addition to the economic and environmental aspects of the home environment, this research considers the elderly's characteristics and experiences in a sustainable remodeling process that emphasizes aging in place. Aging in place means that people grow older in their homes and do not need to move into institutionalized care facilities. This is broadly recognized to be desirable for both older people and governments [11]. Affordable and appropriate housing could play a fundamental role in enabling active and independent living for older people, which could decrease demands on aged care systems [12]. First, to achieve the aim of this research, related work on energy performance in buildings was critically reviewed and remodeling components associated with energy efficiency were identified. Second, based on the remodeling components derived from related work, key factors in the remodeling process for the elderly were investigated. Finally, the framework for a remodeling process enabling energy efficiency was proposed to support green home upgrades for the elderly.

Many previous energy-related studies have dealt with quantitative energy savings and optimization, emphasizing the efficient management of energy. However, this study differs in approach, considering the link between aging and health of the elderly and green remodeling for energy saving in housing in light of the socio-demographic changes inherent in an 'aging society'. This study emphasizes that energy savings of buildings to maintain a sustainable environment are very important because the fast-growing cohort of the elderly worldwide comprises the majority of the energy consumers. In addition, the elderly needs customized remodeling to reflect their health and other needs in the place in which they live. Since many countries support the cost of remodeling of the houses of the elderly as a part of welfare policy, it is necessary to induce optimal use of the financial support from the government for remodeling for energy efficiency. In particular, green building and eco-friendly architectural planning approaches emphasizing the improvement of energy performance in buildings are highly needed in the remodeling of aging buildings as one energy saving strategy, because those approaches can provide a 'green upgrade' in energy performance at a reasonable cost. It is expected that the result of this research will contribute to increasing knowledge in the domain of energies. 


\section{Energy Efficiency and Home Remodeling}

\subsection{Energy Performance in Buildings}

Many building environmental assessment schemes, such as LEED (Leadership in Energy and Environmental Design), BREEAM (Building Research Establishment Environmental Assessment Method), and CASBEE (Comprehensive Assessment System for Built Environment Efficiency), have been developed internationally. There is variation among these assessment schemes both in performance criteria and the organization of certificate systems [13]. Table 1 summarizes sustainability-related evaluation items derived from five certificate systems $[14,15]$. The concept of sustainability in housing often deals with issues such as limited resources, especially energy, to lessen the effects of development on the natural environment [2]. The implementation of sustainability through green building is important in the built environment because green building can increase building energy performance and improve the occupants' health [10]. In Table 1, "Thermal environment" includes the control of temperature and humidity in each space and the use of renewable energy. "Air environment" deals with the evaluation of air purification, ventilation, and hygiene, considering the ambient conditions and avoiding the use of hazardous finishing materials. "Light environment" includes the evaluation of the level of sunshine and natural light within the house, the appropriate level of illumination of the artificial lighting, and the related equipment. The items related to sustainability in environmentally friendly buildings and green remodeling are generally associated with the conditions and methods of maintaining the temperature, air, and light environments of buildings, considering the surrounding natural conditions, and the equipment plan for the appropriate level and use of renewable energy resources in controlling the buildings artificially.

Table 1. Evaluation Items of Eco-Friendly Architecture and Green Remodeling.

\begin{tabular}{|c|c|c|c|}
\hline Certificate System & Thermal Environment & Air Environment & Light Environment \\
\hline \multirow{2}{*}{$\begin{array}{c}\text { GBCC (Green Building } \\
\text { Certification Criteria) }\end{array}$} & \multirow{2}{*}{$\begin{array}{l}\text { Use of an automatic thermostat } \\
\text { for each room }\end{array}$} & $\begin{array}{c}\text { Restrain use of } \\
\text { harmful substances }\end{array}$ & \multirow[t]{2}{*}{ Secure sunshine within the house } \\
\hline & & Degree of ventilation design & \\
\hline \multirow{2}{*}{$\begin{array}{l}\text { LEED (Leadership in Energy and } \\
\text { Environmental Design) }\end{array}$} & \multirow{2}{*}{ Supply of heating and cooling } & Air purification & \multirow{2}{*}{-} \\
\hline & & Protection from radon & \\
\hline $\begin{array}{l}\text { BREEAM (Building Research } \\
\text { Establishment Environmental } \\
\text { Assessment Method) }\end{array}$ & - & - & Natural lighting \\
\hline $\begin{array}{l}\text { CASBEE (Comprehensive } \\
\text { Assessment System for Built } \\
\text { Environment Efficiency) }\end{array}$ & $\begin{array}{l}\text { Room temperature, humidity } \\
\text { control, and monitoring }\end{array}$ & $\begin{array}{l}\text { Applicability of the air } \\
\text { environment conforming to } \\
\text { building standards (no smoking, } \\
\text { ventilation, } \mathrm{CO}_{2} \text { monitoring) }\end{array}$ & $\begin{array}{l}\text { Measurement of anti-glare of } \\
\text { daylighting, illuminance level, } \\
\text { and lighting }\end{array}$ \\
\hline Green Remodeling & $\begin{array}{l}\text { Insulation for air tightness and } \\
\text { anti-condensation, heat source } \\
\text { equipment, solar heating } \\
\text { equipment, } \\
\text { geothermal equipment }\end{array}$ & $\begin{array}{l}\text { Ventilation for external weather } \\
\text { conditions, ventilation and } \\
\text { control, sanitary equipment, } \\
\text { control equipment }\end{array}$ & $\begin{array}{l}\text { Lighting equipment, photovoltaic } \\
\text { equipment, control equipment }\end{array}$ \\
\hline
\end{tabular}

Recent research has been carried out on green remodeling in connection with the improvement of energy efficiency in buildings. Many researchers have worked on the energy performance related to remodeling of houses. Wilson and Jacob [3] considered the economic aspects of housing energy efficiency and the health aspects of residents by classifying them according to categories, such as insulation, windshield, heating repair and relocation, window and door relocation, and ventilation. For the economic aspects of energy performance, the concept of passive houses using solar panels is often applied in the remodeling of houses $[16,17]$. Harmless finishing materials, carbon monoxide alarms, and smoke alarms are often suggested in the remodeling of houses considering energy performance and health $[18,19]$. It is desirable to consider the economic and health aspects of residents in addition to the physical aspect of the environment when supporting energy performance in remodeling houses. Residents' overall health could be improved through remodeling that considers the thermal environment, the air environment, and the light environment. In particular, the monitoring 
of pollutants that determine the IAQ (indoor air quality) could alleviate respiratory diseases, such as asthma, and hypertension. This would minimize the economic burden of residents by reducing healthcare costs. Figure 1 links the effects of energy efficiency from remodeling with energy performance in houses.

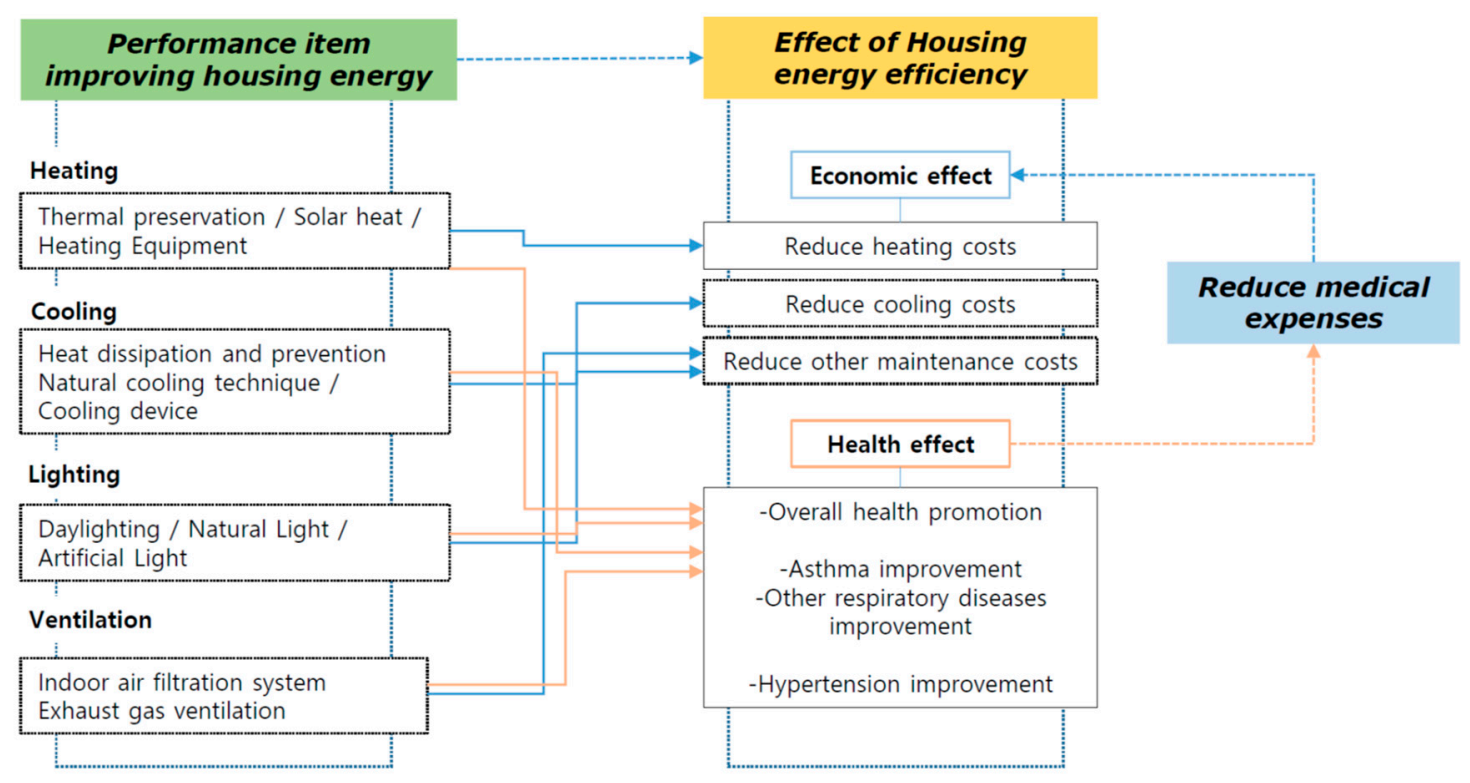

Figure 1. Correlation of energy performance items and the effect of housing energy efficiency.

There are many different energy-saving strategies that can be implemented in houses. Therefore, architects often have difficulty prioritizing the application of appropriate strategies in the process of energy performance improvement and efficient management [10]. To solve this difficulty for energy-saving strategies, Lechner [20] suggested a three-tier approach including the first tier of basic building design approaches, the second tier of passive systems, and the third tier of mechanical equipment. These were classified into categories, such as heating, cooling, and lighting, with detailed elements. Space area items for heat conservation, solar heat utilization, and detailed plans for heating equipment were provided for the heating system. Consideration items, such as shadows and colors for heat prevention, natural cooling techniques, and detailed plans of the cooling equipment were considered for the cooling system. For the light system, daylight should be secured by considering windows and interior finishing, and detailed information about related machinery and electrical equipment should be provided for lighting installation, considering skylights and shadows.

\subsection{Home Remodeling for the Elderly}

The aging of older people generally manifests as physical, mental, and social dysfunction. Therefore, a multidimensional approach is needed. Aging is associated with multiple impairments from three medical perspectives: physical impairment, function impairment, and total impairment [21]. Previous housing remodeling for the elderly has mainly focused on the modification of the physical environment. However, it is necessary to consider the non-physical environment using a multidimensional approach, considering the elderly's mental and social dysfunction. For example, Korean standards and manuals for home remodeling have limitations in supporting older people's mental and social functions because they are dominated by planning factors for indoor and outdoor environments. To overcome these limitations, Choi and Park [22] critically reviewed previous research on the elderly's housing and the key theories, such as evidence-based design, universal design, and biophilic design, and proposed nine application areas for remodeling and 43 remodeling items considering the elderly's multidimensional characteristics. The nine application areas of remodeling 
are furniture planning, openings planning, smart home systems, space planning, circulation planning, auxiliary and supporting equipment planning, finishing materials and color planning, lighting planning, and IAQ planning.

As shown in Table 2, this study deals with six application areas of remodeling related to the improvement of energy performance in housing for the elderly: openings, space, smart home systems, material and color, the quality of indoor environment, and lighting. Twelve remodeling items with detailed elements were derived, focusing on interrelations with energy efficiency.

Table 2. Remodeling Elements Related to the Improvement of Energy Performance in Housing for the Elderly.

\begin{tabular}{|c|c|c|c|c|c|c|c|c|c|c|c|c|c|}
\hline \multirow{2}{*}{ Remodeling Area } & \multirow{2}{*}{ Remodeling Item } & \multirow{2}{*}{ Remodeling Elements } & \multicolumn{3}{|c|}{1} & \multicolumn{3}{|c|}{2} & \multicolumn{3}{|c|}{3} & \multicolumn{2}{|c|}{4} \\
\hline & & & $\mathbf{A}$ & B & C & D & $E$ & $F$ & G & $\mathbf{H}$ & I & $\mathrm{J}$ & K \\
\hline $\begin{array}{l}\text { Opening: window, } \\
\text { door, gate }\end{array}$ & $\begin{array}{l}\text { View of a natural } \\
\text { ecosystem }\end{array}$ & $\begin{array}{l}\text { Provide natural lighting through } \\
\text { installing side windows, skylights, } \\
\text { and front windows }\end{array}$ & & & & & & & 0 & O & & & \\
\hline \multirow[t]{2}{*}{ Smart home system } & \multirow{2}{*}{$\begin{array}{c}\text { Indoor } \\
\text { environment/energy } \\
\text { management }\end{array}$} & $\begin{array}{l}\text { Install integrated controller, remote } \\
\text { control device showing energy } \\
\text { usage and meters, sensors around } \\
\text { windows, gate, and } \\
\text { automatic ventilation }\end{array}$ & & & 0 & & & O & 0 & & 0 & $\circ$ & 0 \\
\hline & & $\begin{array}{l}\text { Install occupancy lighting, sensors } \\
\text { and remote controls, and automatic } \\
\text { time lighting }\end{array}$ & & & & & & & 0 & & 0 & & \\
\hline Space area & Proper spatial area & $\begin{array}{l}\text { Optimize spatial areas of rooms } \\
\text { and corridors }\end{array}$ & & & & & & & & & & & \\
\hline \multirow{4}{*}{ Materials and color } & \multirow{2}{*}{ Finish materials } & $\begin{array}{l}\text { Use a matte-type of material to } \\
\text { prevent reflection }\end{array}$ & 0 & & & 0 & & & 0 & & & & \\
\hline & & $\begin{array}{l}\text { Install floor heating for drying } \\
\text { slippery surfaces }\end{array}$ & 0 & & O & & & & & & & & \\
\hline & \multirow[t]{2}{*}{ Color } & $\begin{array}{l}\text { Use high saturation and low } \\
\text { saturation planning for the main } \\
\text { color scheme }\end{array}$ & & 0 & & & 0 & & 0 & & & & \\
\hline & & $\begin{array}{l}\text { Use green colors considering } \\
\text { solitude and nervous breakdown }\end{array}$ & & & & & & & O & & & & \\
\hline \multirow{4}{*}{$\begin{array}{l}\text { The quality of the } \\
\text { indoor } \\
\text { environment }\end{array}$} & Ventilation equipment & $\begin{array}{l}\text { Install ventilation on top of heating } \\
\text { stand of kitchen }\end{array}$ & & & & 0 & 0 & & & & & 0 & 0 \\
\hline & IAQ & $\begin{array}{l}\text { Install sensors monitoring fine dust, } \\
\text { nitrogen dioxide, carbon monoxide, } \\
\text { carbon dioxide, and VOC }\end{array}$ & & & & & & & & & & O & 0 \\
\hline & Thermal environment & $\begin{array}{l}\text { Install sensors monitoring } \\
\text { thermal environment }\end{array}$ & & & 0 & & & & & & & & \\
\hline & Lighting environment & $\begin{array}{l}\text { Install sensors monitoring } \\
\text { illuminance and luminance }\end{array}$ & & & & & & & O & O & $\bigcirc$ & & \\
\hline \multirow{3}{*}{ Lighting } & $\begin{array}{c}\text { Light for } \\
\text { behavioral support }\end{array}$ & $\begin{array}{l}\text { Install devices adjusting } \\
\text { illumination control and safety } \\
\text { lighting for stairs and steps on floors } \\
\text { and provide average illumination } \\
\text { (600-1000 lx) for the elderly }\end{array}$ & & & & & & & & O & 0 & & \\
\hline & Natural lighting & $\begin{array}{l}\text { Provide a lively environment with } \\
\text { nature through various lights and } \\
\text { shadows using windows and blinds }\end{array}$ & & 0 & & 0 & O & & & & & & \\
\hline & $\begin{array}{l}\text { Artificial lighting } \\
\text { equipment for safety }\end{array}$ & $\begin{array}{l}\text { Install a wall light fixture on the } \\
\text { vanity mirror and install bottom } \\
\text { lighting for moving line at night }\end{array}$ & & & & & & & & 0 & 0 & & \\
\hline
\end{tabular}

1: Heating, 2: Cooling, 3: Lighting, 4: Ventilation. A: Thermal Preservation, B: Solar Heat, C: Heating Equipment, D: Heat Dissipation, E: Natural Cooling, F: Cooling Equipment, G: Daylight, H: Natural Lighting, I: Artificial Lighting, J: Indoor Air, K: Ventilation.

For the openings of the housing for the elderly, adequate space, easy opening and closing of handles and locks, and views for observing changes in natural ecosystems should be provided [23-26]. Barrier-free space planning that considers the mobility of the elderly should be developed by securing appropriate space in private rooms and passages and effective space. In addition, it is desirable to induce spiritual and psychological healing by creating natural ecosystems in the space [27-29]. Through smart home systems, such as sensors, devices, and controllers that support the health, culture, and leisure of the elderly, the management of indoor environments and energy, household activities, security and safety, and the physical, mental, and social functions of the elderly could be 
supported [3,30]. Taking into account the color discrimination capability and responses of the elderly, finishing materials and color plans that support the elderly's mental health, such as stress, depression, and memory assistance, should be developed [10,31-36]. The lighting plan should consider proper illumination of artificial lighting to support the elderly's work and activities and local lighting of stairways and floors for guidance at night [35]. Natural lighting is an important factor that could allow the elderly to recognize changes in time and relieve their depression [36]. The IAQ in bedrooms affects older people's sleep efficiency and, therefore, it is necessary to link IAQ sensors to automatic ventilation systems. In addition, it is very important for older people's houses to have sensors to measure noise, light, and heat to prevent the elderly from being exposed to harmful environments and to facilitate the management of the indoor environment and energy in houses integrally through the Internet of Things (IoT) [19].

\section{A Framework for Green Remodeling Enabling Energy Efficiency in Housing for the Elderly}

This study proposes the framework for green remodeling enabling energy efficiency for housing for the elderly, including six application areas and detailed remodeling elements. The key benefit of the proposed system is that it will provide stakeholders with a guideline for developing a remodeling process for housing for the elderly that focuses on energy efficiency and healthy living. In the remodeling process, stakeholders should consider the life-cycle costs of energy-saving in addition to the initial cost by reducing the operation and maintenance costs of housing. Although it is hard to provide quantification of the costs associated with the proposed process, it is expected that energy-efficient remodeling provides many benefits in terms of maintenance costs by decreasing the life-cycle cost of housing. Thus, the expansion of energy-efficient remodeling strategies for existing buildings is critical to green home upgrades in terms of energy performance. In this paper, an energy-efficient remodeling process is developed to facilitate energy-saving strategies for existing buildings.

Considering the multidimensional features of the elderly, the remodeling process of the housing for the elderly should be different from the remodeling process of other housing. As shown in Table 2, for the process of remodeling of housing for the elderly, the application areas and the items of remodeling should reflect the elderly's physical, mental, and social dysfunctions. The proposed remodeling items and elements for the elderly could improve the physical and mental function of the elderly and also economic efficiency by optimizing energy consumption. In this way, it could reduce the medical costs of the elderly.

Figure 2 illustrates the three components of the remodeling system that enable energy efficiency in the housing for the elderly. The first component includes remodeling planning items related to cooling, heating, lighting, and ventilation of housing, and is focused on the sustainability of buildings to save energy. The second component includes remodeling planning factors and items that are relevant to energy efficiency that consider the multidimensional nature of the elderly. The third component presents the economic and health effects on the elderly, considering the correlation between the first and second components mentioned above. The proposed remodeling process for energy-efficient housing for the elderly consists of 20 items of detailed plans related to the improvement of energy performance in terms of the heating, cooling, light, and ventilation, as well as factors such as planning of space areas, finishing and color, lighting, smart indoor environments, and integrated energy management. Overall, it was found that lighting planning, finishing and color planning, smart indoor environment control, and installation of energy management systems play an important role in the improvement of housing energy performance.

First, the planning of space areas considers the optimized area of each room and the movement of the older person who may have physical difficulties. Second, the planning of lighting and illuminance includes designing the indoor environment to admit sufficient natural light to recognize seasonal and temporal change and also includes controlling the lighting automatically. Natural light is critical to the elderly's mental stability because it can attract nature to the indoor space through changes in light and shadow. The inflow of natural light relates to the selection of floor finish. It is necessary to use 
a matte finish with low reflection to prevent glare. In the case of artificial lighting, it is necessary to install sensors in steps or stairways of the indoor environment to consider the elderly person's safety. Bottom lighting is necessary to prevent sudden glare at night. Third, regarding the planning of finishing materials and color, finishing materials with low reflectance should be selected to secure visibility for the elderly. Finishing materials suitable for floor heating equipment that can dry surfaces should be selected to prevent slippage in the bathroom. The planning of color should consider a green-based color scheme to relieve the solitude and any possible nervous breakdowns of the elderly. Colors of high and low saturation are needed for the main color plan, which should consider color reactions, such as the yellow change phenomenon of the elderly. Finally, planning of the smart indoor environment and energy management includes the installation of an automatic ventilation system for maintaining the quality of the indoor environment, sensors for monitoring harmful substances, such as fine dust, VOC, and carbon oxide, and a controller.

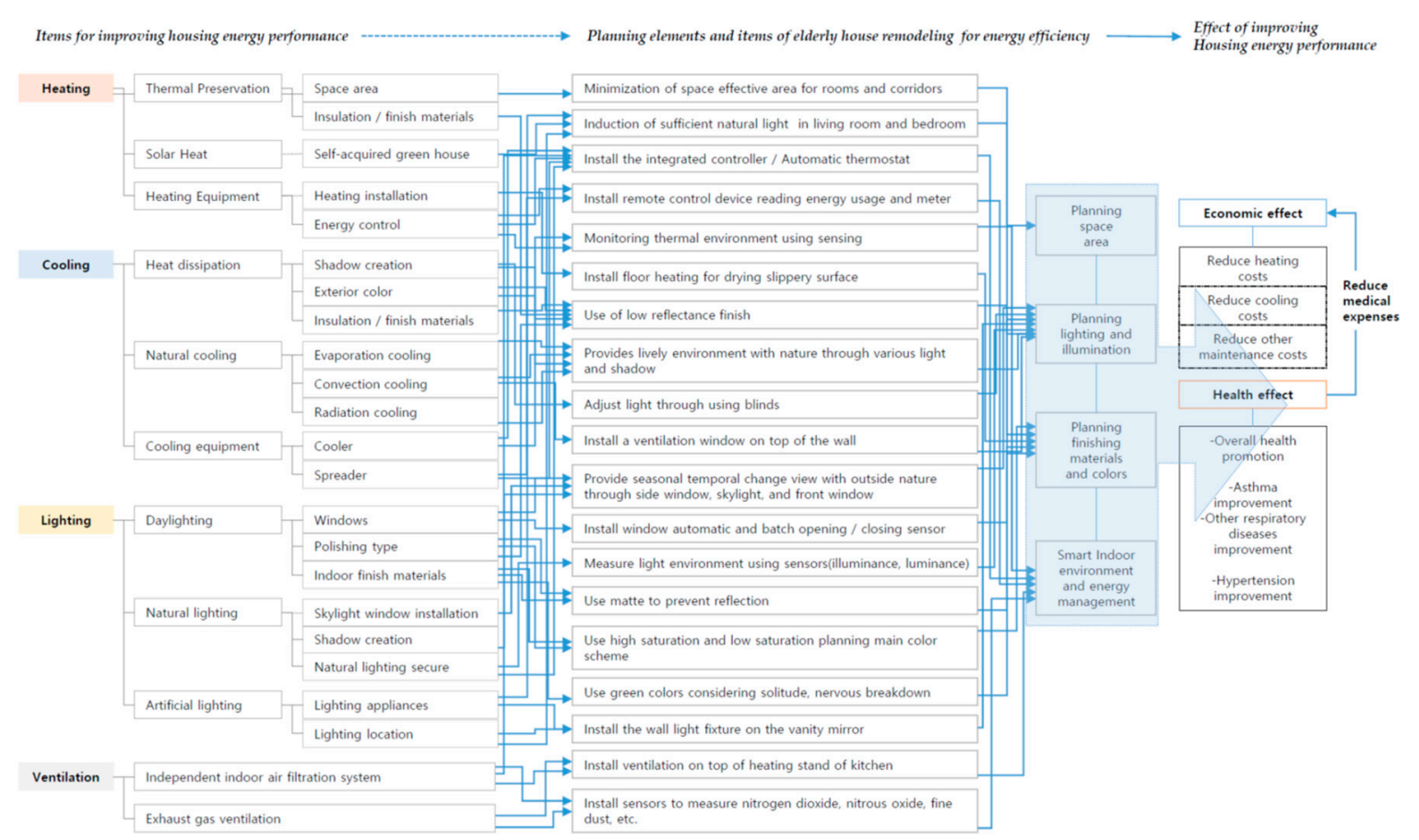

Figure 2. A remodeling system enabling energy efficiency in the housing for the elderly.

Most importantly, to support the declining memory of the elderly, an integrated controller for the thermal environment and lighting should be provided to manage energy efficiently, in addition to a remote energy meter reading. Many older people have chronic diseases, such as respiratory diseases, asthma, and hypertension. Therefore, plans to efficiently manage ventilation equipment, heating, and cooling are needed. The plan to maximize natural ventilation through proper positioning of openings is significant.

\section{Discussion}

The results of this research are as follows.

First, for this research, the relation between items of heating, cooling, light, and ventilation associated with the improvement of housing energy performance and items of housing remodeling that consider the elderly's characteristics was examined. Details of remodeling of housing for the elderly were presented based on various theories, such as a barrier-free, universal design considering the safety and convenience of the physical environment, evidence-based design considering the diverse characteristics of the elderly, biophilic design, and smart housing services. From this integrated viewpoint, the clue to a housing remodeling process that considers energy performance and efficiency 
was derived for promoting the health of the elderly. Second, the details of remodeling of houses for the elderly to improve energy performance were derived in terms of space area planning, lighting planning, material and color planning, smart indoor environment, and energy management. This study emphasized the four items and details as the most effective way to improve energy performance and efficiency in the remodeling of housing for the elderly. Finally, the four remodeling factors that should be considered first in the proposed remodeling process emphasize effective planning methods in connection with energy efficiency to maintain the health of the elderly, leading to a reduction in the medical expenses for the elderly. That is, the green remodeling process for energy-efficient housing for the elderly should be carried out considering the economic and health effects on the elderly.

Previous studies have addressed the improvement of energy performance in home remodeling for the general population. This study dealt specifically with energy efficiency in the remodeling of housing for the elderly. Although all people are interested in the efficient use and management of energy, it would be very expensive to plan all the details for remodeling by the government or individuals. It is necessary to determine specific remodeling items that are more effective and efficient for the elderly's housing. It is expected that improving the energy performance of houses for the elderly, who account for the largest proportion of the population at the national level, could save energy resources at national and global levels, leading to an economically effective outcome. It is expected that the health cost saving through the maintenance of healthy living will be effective because the remodeling details consider the multidimensional health of the elderly. In this research, the role of designers is emphasized and it is argued that intelligent housing, using IT-based technology, should be planned, in addition to improving the physical environment of the house for energy efficiency. Mental health of the elderly should also be improved via nature for healthy living, as the improvement in energy efficiency should be attained using natural means.

\section{Conclusions}

Because of rapid industrial development, environmental problems are becoming social issues to be solved. There is a great interest in sustainable development that can conserve resources and energy. There is an increasing interest in developing architectural plans focused on sustainability to slow the aging of buildings or improve functioning through the remodeling process. In the case of newly constructed buildings, it is difficult to maintain surrounding environments because of construction waste. This research highlights the need for a green remodeling system for housing for the elderly to be further refined to link the energy performance of housing to health effects. Energy efficiency could play a critical role in the improvement of energy consumption and in achieving sustainable development. Therefore, there should be a connection between energy-efficient design and sustainable housing development.

This study dealt with a home remodeling plan for the improvement of energy efficiency while considering the elderly's characteristics and experiences. The development of a sustainable architectural environment is very important for the efficient management and use of energy. Recently, in the field of building energy performance, the approach to the improvement of energy efficiency has changed from a passive to an active perspective. Buildings should be planned from the viewpoint of human-centered design, considering residents in new building construction or building remodeling. From this point of view, this study is significant because it proposed a green remodeling process for a healthy, functional, and affordable living environment for older people by improving energy efficiency in housing. It targeted residents who constitute a large proportion of our society-the elderly. The conceptual approach of the green remodeling in this study emphasizes the strength of remodeling of housing for the elderly for smart energy savings from the construction and architectural perspectives. Energy-efficient home upgrades are critical for successful energy management of their homes and their health and wellbeing. Since it is difficult for the elderly to identify how they would apply a green remodeling process in their housing, we have tried to develop more specific remodeling solutions for energy management and to encourage the recognition and participation of the elderly 
through consulting led by government agencies. Remodeling rather than constructing new buildings is considered to be sustainable and, from the viewpoint of continuity theory in the field of gerontology, aging in place is considered to maintain the total health of the elderly. The research themes emphasized in this study were different from those of other studies.

Author Contributions: Formal analysis: S.J.P.; Funding acquisition: S.J.P. and M.J.K.; Investigation: S.J.P.; Supervision: M.J.K.; Writing—original draft: S.J.P. and M.J.K.; Writing—review and editing: M.J.K.

Funding: This research was funded by the National Research Foundation of Korea Grant (the Korean government fund) NRF-2016R1A2B4007752 and NRF-2018R1C1B6008735.

Conflicts of Interest: The authors declare no conflict of interest.

\section{References}

1. Kim, M.J.; Oh, M.W.; Cho, M.E.; Lee, H.; Kim, J.T. A Critical review of user studies on heath smart homes. Indoor Built Environ. 2013, 22, 1-11. [CrossRef]

2. Roufechaei, K.M.; Bakar, A.H.A.; Tabassi, A.A. Energy-efficient design for sustainable housing development. J. Clean. Prod. 2014, 65, 380-388. [CrossRef]

3. Wilson, J.; Jacobs, D. Health and Home Upgrades. ASHRE J. 2017, 59, 66-68.

4. Miller, W.; Vine, D.; Amin, Z. Energy efficiency of housing for older citizens: Does it matter? Energy Policy 2017, 101, 216-224. [CrossRef]

5. Choi, H.K.; Park, S.J. A Home Remodeling to Improve Energy Efficiency for the Elderly; Architectural Institute of Korea: Seoul, Korea, 2017; pp. 120-123.

6. Patulny, R. The golden years? Social isolation among retired men and women in Australia. Fam. Matters 2009, 83, 39-47.

7. Maller, C.J.; Strengers, Y. Housing, heat stress and health in a changing climate: Promoting the adaptive capacity of vulnerable households, a suggested way forward. Health Promot. Int. 2011, 26, 492-498. [CrossRef] [PubMed]

8. Howden-Chapman, P;; Chapman, R. Health co-benefits from housing-related policies. Curr. Opin. Environ. Sustain. 2012, 4, 414-419. [CrossRef]

9. Romanach, L.; Hall, N.; Meikle, S. Energy consumption in an ageing population: Exploring energy use and behavior of low-income older Australians. Energy Procedia 2017, 121, 246-253. [CrossRef]

10. Lee, K.; Koo, B.; Park, B.; Ahn, Y.H. The development of an energy-efficient remodeling framework in South Korea. Habitat Int. 2016, 53, 430-441. [CrossRef]

11. Judd, B.; Olsberg, D.; Quinn, J.; Groenhart, L.A.; Demirbilek, O. Dwelling, Land and Neighborhood Use by Older Home Owners; Australian Housing and Urban Research Institute: Melbourne, Australia, 2010.

12. WHO Active Ageing: A Policy Framework; WHO: Geneva, Switzerland, 2002.

13. Boech, L.D.; Verbeke, S.; Audenaert, A.; Mesmaeker, L.D. Improving the energy performance of residential buildings: A literature review. Renew. Sustain. Energy Rev. 2015, 52, 960-975.

14. Lee, S.N.; Park, J.C.; Rhee, E.K. An Analysis of performance assessment factors of indoor environmental quality in multi-family housing using post occupancy evaluation. J. Korean Sol. Energy Soc. 2011, 31, 128-134. [CrossRef]

15. Ministry of Land, Infrastructure, Transport and Tourism. Green Remodeling Project Planning Guideline; South Korea Government: Seoul, Korea, 2013; pp. 45-60.

16. Lloyd, E.L.; McCormack, C.; McKeever, M.; Syme, M. The effect of improving the thermal quality of cold Housing on blood pressure and general health: A research note. J. Epidemiol. Community Health 2008, 62, 793-797. [CrossRef] [PubMed]

17. Wallner, P.; Munoz, U.; Tappler, P.; Wanka, A.; Kundi, M.; Shelton, J.F.; Hutter, H.P. Indoor environmental quality in mechanically ventilated, energy-efficient buildings vs. conventional buildings. Int. J. Environ. Res. Public Health 2015, 12, 14132-14147. [CrossRef] [PubMed]

18. Leech, J.A.; Raizenne, M.G.J. Health in occupants of energy efficient new homes. Indoor Air 2004, 14, 169-173. [CrossRef] [PubMed]

19. Breysse, J.; Jacobs, D.E.; Weber, W.; Dixon, S.; Kawecki, C.; Aceti, S.; Lopez, J. Health outcomes and green renovation of affordable housing. Public Health Rep. 2011, 126, 64-75. [CrossRef] [PubMed] 
20. Lechner, N. Heating, Cooling, Lighting: Sustainable Design Methods for Architects; John Wiley \& Sons, Inc.: New York, NY, USA, 2009.

21. WHO Mental Health: New Understanding, New Hope; WHO: Geneva, Switzerland, 2001.

22. Choi, H.K.; Park, S.J. The Preference on House Modification According to Multiple Chronic Disease of the Elderly; The Korean Institute of Culture Architecture: Seoul, Korea, 2017; Volume 58, pp. 71-82.

23. Ministry of Land, Infrastructure, Transport and Tourism. Manual of Housing Remodeling for the Elderly; South Korea Government: Seoul, Korea, 2007; pp. 35-47.

24. Cornell University. Gerontological Environment Modification Environmental Assessment; Cornell University: New York, NY, USA, 2005; pp. 3-14.

25. Oh, C. A Case study on the evaluation of small-sized apartment houses in aspects of universal design. Korean Inst. Inter. Des. 2013, 22, 20-31.

26. Lee, H.S.; Lim, H.W.; Park, S.J. The smart service pattern-oriented kitchen using the behavior patterns of the elderly according to the aging steps. Arch. Inst. Korea 2013, 29, 75-82.

27. EBD House P Ltd. Evidence-based design-Aged care. EBD J. 2014, 6-11. Available online: http:// ebdjournal.com/journals/aged-care (accessed on 4 July 2018).

28. Lim, H.W.; Lee, H.S. The smart services of the hazard management in the kitchen for the elderly. Arch. Inst. Korea 2013, 29, 139-146.

29. Lee, E.J.; Park, S.J. The application of bio-philic design pattern in housing for cure of mental health-Focused on the elderly and baby-boomer. Arch. Inst. Korea 2018, 34, 13-21.

30. Lee, H.W.; Park, S.J.; Kim, M.J.; Jung, J.Y.; Lim, H.W.; Kim, J.T. The service pattern-oriented smart bedroom based on elderly spatial behaviour patterns. Indoor Built Environ. 2013, 22, 299-308. [CrossRef]

31. Kim, Y.R. Interior Coloring Plan for Space Ability Improvement of the General Welfare Institution for the Aged; Dongduk Women's University: Seoul, Korea, 2004.

32. Cho, K.J. Study on the Interior Planning of Independent Housing for the Aged Men; Kookmin University: Seoul, Korea, 2005.

33. Han, H.S.; Park, H.C. A study on the color scheme of elderly room. J. Korea Society Color Studies 2011, 25, 5-15. [CrossRef]

34. Jung, M.R. A Study on interior flooring materials for safe elderly nursing home environment. J. Korean Hous. Assoc. 2014, 25, 19-26.

35. Mccullough, C.S. Evidence-Based Design for Healthcare Facilities; SIGMA Theta Tau International, Center for Nur: Indianapolis, IN, USA, 2010.

36. Ryan, C.O.; Browning, W.D.; Clancy, J.O.; Andrews, S.L.; Kallianpurkar, N.B. Biophilic design patterns: Emerging nature-based parameters for health and well-being in the built environment. Int. J. Arch. Res. 2014, 8, 62-76. [CrossRef]

(C) 2018 by the authors. Licensee MDPI, Basel, Switzerland. This article is an open access article distributed under the terms and conditions of the Creative Commons Attribution (CC BY) license (http:// creativecommons.org/licenses/by/4.0/). 